\title{
Optimization of chemical induction for evaluation of endogenous retroviruses in different species
}

\author{
Hailun Ma, Yunkun Ma, Wenbin Ma, Dhanya K Williams, Teresa A Galvin, Syed Shaheduzzaman, Arifa S Khan \\ From Frontiers of Retrovirology 2011 \\ Amsterdam, The Netherlands. 3-5 October 2011
}

\begin{abstract}
Background
Chemical inducers such as 5-azacytidine (AzaC) and 5'iodo-2'deoxyuridine (IUdR) have been used to discover and characterize endogenous retroviruses from rodent and avian speciecs, for example KBALB mouse cells. We found that induction conditions that have been optimized for mouse cells were not successful in inducing retrovirus from cell lines of other species, including nonhuman primates. Therefore, we developed a stepwise strategy based upon identification of critical parameters for endogenous retrovirus induction in mouse cells for optimizing induction conditions for non-murine cells. Using this approach, we have determined optimum conditions for investigating inducible endogenous retroviruses from Vero cells, which are of African green monkey (AGM) origin, a species that has never been reported to produce endogenous retroviruses [1].
\end{abstract}

\section{Materials and methods}

Based upon a step-wise induction strategy [2], Vero cell growth characteristics such as growth curve, population doubling time, and cell cycle phase were determined; drug dose range was obtained by evaluating cell toxicity and cell recovery using different drug concentrations (lUdR, 50 - 3,200 ug/ml; AzaC, 0.2125 - $40 \mathrm{ug} / \mathrm{ml}$; and NaBut, 1 - $6 \mathrm{mM}$ ). Cellular RNAs were tested for endogenous retrovirus activation using virus-specific PCR assays and filtered supernatants were analyzed for virus particle production using a highly-sensitive RT assay and PCR assays [1]. Infectivity studies were done using various cell lines from different species based upon their susceptibility to known retrovirus infections. Cellular RNAs from untreated and AzaC-treated cells will be

Laboratory of Retroviruses, Division of Viral Products, Center for Biologics Evaluation and Research, U.S, Food and Drug Administration, Bethesda, Maryland, 20892, USA evaluated for virus induction using different emerging virus detection technologies.

\section{Results}

The results demonstrated that endogenous retrovirus particles could be induced from Vero cells under optimized cell growth and drug treatment conditions. Molecular analysis indicated that the particles contained gag, pol, and env regions related to endogenous SERV and $\mathrm{BaEV}$ sequences previously reported in the AGM DNA. Biological studies showed no evidence of replicationcompetent particles using several target cell lines. Similarly, an RT activity could be induced from a dog cell line, which is another species with no evidence of retrovirus isolation. This is currently under investigation for further characterization.

\section{Conclusions}

The induction of retrovirus particles from Vero cells was low and detected in cell-free supernatant only by using a highly sensitive PCR-based RT assay and virusspecific PCR assays. Further investigations of various emerging virus detection technologies used for novel virus discovery has demonstrated that induced viral RNAs could be detected in drug-treated cells using high throughput 454-massively parallel or deep sequencing: investigations with virus microarrays and long range PCR with mass spectrometry are ongoing. The results support that the combination of chemical induction strategy with sensitive broad virus detection technologies may be used for the discovery of novel endogenous retroviruses.

Published: 3 October 2011 


\section{References}

1. Ma H, Ma Y, Ma W, Williams DK, Galvin TA, Khan AS: Chemical induction of endogenous retrovirus particles from the Vero cell line of African green monkeys. J Virol 2011, 85:6579-6588.

2. Khan AS, Ma W, Ma Y, Kumar A, Williams DK, Muller J, Ma H, Galvin TA: Proposed algorithm to investigate latent and occult viruses in vaccine cell substrates by chemical induction. Biologicals 2009, 37:196-201.

doi:10.1186/1742-4690-8-S2-P38

Cite this article as: Ma et al:: Optimization of chemical induction for evaluation of endogenous retroviruses in different species. Retrovirology 2011 8(Suppl 2):P38.

Submit your next manuscript to BioMed Central and take full advantage of:

- Convenient online submission

- Thorough peer review

- No space constraints or color figure charges

- Immediate publication on acceptance

- Inclusion in PubMed, CAS, Scopus and Google Scholar

- Research which is freely available for redistribution

Submit your manuscript at www.biomedcentral.com/submit
() Biomed Central 